\title{
HR Biznes Partner - geneza oraz funkcje we współczesnych organizacjach
}

\author{
Milena Rogala \\ Szkoła Główna Handlowa w Warszawie
}

\begin{abstract}
W artykule przedstawiono wyniki badania dotyczącego popularyzacji funkcji Human Resource Business Partner (HR BP, HR Biznes Partner) we współczesnych przedsiębiorstwach. Na podstawie studium literatury z zakresu zarządzania zasobami ludzkimi oraz HR BP opracowano wzorcowy zakres obowiązków HR BP. Zestawiono go następnie z przykładami praktycznymi w postaci analizy dokumentów wewnętrznych oraz wynikami badania ankietowego przeprowadzonego wśród osób zajmujących stanowiska w działach HR różnych firm. Rezultaty przeprowadzonych badań i analiz świadczą o tym, że nazwa stanowiska HR BP nie zawsze odnosi się do zadań przypisanych tej roli we wzorcowym zakresie obowiązków. I odwrotnie, wypełnienie wzorcowego zakresu obowiązków przez pracowników działu HR w założonym minimum nie zawsze niesie za sobą nazwę stanowiska HR Biznes Partner.
\end{abstract}

Słowa kluczowe: zarządzanie zasobami ludzkimi, HR, HR Biznes Partner, zakres obowiązków Kod klasyfikacji JEL: M54 


\section{W prowadzenie}

Wzrost zainteresowania tematyką zarządzania zasobami ludzkimi wynika ze zmiany sposobu postrzegania zasobów ludzkich organizacji. Zaczęły one być bowiem nie tylko kosztem dla organizacji, ale także jej kluczowym czynnikiem strategicznym oraz źródłem przewagi konkurencyjnej. Wyzwania, przed jakimi staje ten obszar zarządzania, dotyczą dynamicznych przemian gospodarczych, społecznych, politycznych i ekonomicznych, na które organizacje muszą reagować. Pochodną ich reakcji jest wypracowywanie w praktyce nowych metod i wzorców, również w obszarze zarządzania personelem. Niektóre z nich są jedynie chwilowymi trendami, inne na stałe wpisują się w funkcjonowanie działów HR. Jednym z powstałych rozwiązań jest koncepcja HR BP, którego zadaniem jest ścisła współpraca z biznesem oraz wspólna realizacja celów organizacji. Tematem artykułu są geneza oraz funkcje HR BP we współczesnych organizacjach, jego podjęcie ma na celu zbadanie różnic i podobieństw występujących pomiędzy organizacjami w tym obszarze. Założeniem pracy jest przedstawienie wzorcowego zakresu obowiązków HR BP oraz weryfikacja jego użyteczności w środowisku biznesowym za pomocą badań metodą analizy dokumentów wewnętrznych oraz badania ankietowego przeprowadzonego wśród osób zajmujących stanowiska w działach HR w różnych firmach w Polsce.

\section{Teoria zarządzania w obszarze HR BP}

Nowoczesne organizacje wpływają na zmianę postaw i zachowań pracowników. Czynnikami sprawczymi zmian są m.in. bodźce z zewnątrz, które bezpośrednio oddziałują na funkcjonowanie firmy. Otwarcie organizacji na otoczenie, coraz sprawniejszy przepływ informacji oraz kształtowanie się nowych idei, a także fakt występowania $\mathrm{w}$ nich spłaszczonych struktur, koncentracja na procesach oraz budowa zespołów międzyfunkcyjnych i międzyorganizacyjnych - niosą za sobą stawianie nowych wyzwań wobec pracowników (Juchnowicz, 2014, 130). Według Pocztowskiego (2018, 33-34) ZZL (zarządzanie zasobami ludzkimi) we współczesnym ujęciu „obejmuje kształtowanie strategii, procesów, struktur i narzędzi wspierających osiąganie wysokiej efektywności pracy oraz podnoszenie jakości i wartości kapitału ludzkiego jako źródła generowania wartości dla interesariuszy” . Bardzo popularna stała się koncepcja przedstawiająca specjalistów HR w roli partnerów biznesowych, polegająca na dzieleniu odpowiedzialności za wypełnianie celów przedsiębiorstwa z menedżerami oraz wspólne angażowanie się w tworzenie i wdrażanie strategii biznesowej oraz kierowanie firmą (Armstrong, 2016, s. 73). 
Jedną z pierwszych osób, które zaobserwowały potrzebę wdrożenia tej funkcji w organizacjach, był John Storey, który na podstawie wywiadów przeprowadzonych w Wielkiej Brytanii w latach 1986-1988 wskazał cztery role, które powinny występować w dziale personalnym: doradcza, służebna, regulująca, powodująca zmiany (Bogdanowicz, 2016, s. 183).

Jednym ze znanych teoretyków i praktyków z obszaru HR jest Dave Ulrich, który w swojej książce Liderzy zarządzania zasobami ludzkimi zdefiniował koncepcję partnerstwa biznesowego HR (Popieluch, 2018, s. 11). Według autora funkcje działu personalnego to: 1) zarządzanie strategicznymi zasobami ludzkimi, 2) zarządzanie infrastrukturą firmy, 3) zarządzanie wkładem pracy personelu, 4) kierowanie transformacją i zmianami (Ulrich, 2001, 40). Ulrich zdefiniował cztery role partnera biznesowego, których wypełnienie miało generować wymierne efekty dla organizacji w perspektywie krótko- i długoterminowej: partner strategiczny, ekspert w dziedzinie administracji, rzecznik pracowników, animator zmian (Bogdanowicz, 2016, s. 183). Pierwsza, strategiczna rola odnosi się do strategii działalności całego przedsiębiorstwa, w ramach której dział HR powinien koordynować część związaną z kapitałem ludzkim. Rolą HR-u i wymiernym efektem tej funkcji jest przede wszystkim realizacja strategii firmy i podejmowanie działań w tym kierunku (Ulrich, 2001, s. 40-42). Specjaliści ds. personalnych jako „eksperci w dziedzinie administracji” powinni wykrywać i redukować niepotrzebne koszty oraz zwiększać efektywność pracowników w wykonywaniu przez nich zadań (Ulrich, 2001, s. 42-43). „Rzecznik pracowników" powinien umieć słuchać, reagować, a także zaspokajać zmieniające się potrzeby pracowników (Ulrich, 2001, s. 43-45). Specjaliści ds. personalnych jako „animatorzy zmian” mają za zadanie pomagać w określeniu metod zarządzania zmianą - uwzględniając w nich zarówno przeszłość organizacji - jej historię i tradycje - jak i działania wpływające na jej przyszłość. Do ich zakresu obowiązków należy rozpoznawanie obszarów problemowych, budowanie zaufania pracowników do organizacji, rozwiązywanie trudnych sytuacji, a także definiowanie i wdrażanie zmian zgodnie z przyjętym planem (Bogdanowicz, 2016, s. 187).

Ulrichowi zarzucano, że jego model wielozadaniowy jest jedynie inną formą przedstawienia istniejącej wcześniej, klasycznej funkcji HR. W odpowiedzi, biorąc pod uwagę zmiany i rosnącą złożoność kontekstu biznesowego, potrzeby i świadomość pracowników, oczekiwania inwestorów oraz rozwój technologii, wraz z Dickiem Beatty’m stworzył nową koncepcję, według której dotychczasowa rola HR BP została przekształcona w funkcję zawodnika/gracza strategicznego (Popieluch, 2018, s. 12-13). W ramach tej funkcji gracz strategiczny HR współpracuje, angażuje się, kreuje wartość dodaną dla organizacji, pomagając w osiąganiu celów biznesowych. Funkcje, jakie pełni w organizacji, są różne: coach (pomaga menedżerom wykorzystywać w pełni ich potencjał w celu osiągania założonych wyników i umożliwia im 
profesjonalny rozwój), lider HR (stosuje się do zasad, które szerzy w organizacji, promuje postawę i kompetencje liderów poprzez swoje zachowania oraz podejmowane działania), „sumienie” (weryfikuje, czy organizacja postępuje zgodnie z przyjętymi wcześniej normami, zasadami i wartościami moralnymi), facylitator (wspiera wydajność i efektywność pracowników, jest zaangażowany we wdrażanie zmian organizacyjnych, dbając przy tym o zdolność zaadaptowania ich przez poszczególnych pracowników i całe zespoły), „architekt” (pomaga przełożyć ogólne koncepcje na rozwiązania organizacyjne), „budowniczy” (zaprojekowane wcześniej rozwiązania wdraża i zamienia na funkcjonujące standardy) (Popieluch, 2018, s. 12-13).

Kolejna zmiana koncepcji roli HR, jakiej podjął się Ulrich, tym razem wraz z Wayne’em Brockbankiem, polegała na odświeżeniu modelu wielozadaniowego w zarządzaniu zasobami ludzkimi. Zadania specjalistów HR zorientowano w kierunku misji ekspertów funkcjonalnych, rozszerzył się wachlarz pracy HR-u - od funkcji administracyjnej przez rozwiązywanie problemów aż po projektowanie, wdrażanie i szerzenie innowacji, które powstały na podstawie twardych danych. Rolę specjalisty ds. personalnych ujęto wieloaspektowo jako: lidera HR, eksperta funkcjonalnego, partnera strategicznego, dewelopera kapitału ludzkiego oraz rzecznika pracowników (Popieluch, 2018, s. 13-14).

Rozpowszechnienie koncepcji Ulricha i jej ewolucji spowodowało powstanie kolejnych opracowań modelowych obrazujących już stanowisko HR BP. Jednym z nich był model opracowany w 2008 r. przez Corporate Leadership Council (CLC), zakładający cztery role HR BP z przypisanymi im zadaniami: menedżer operacyjny, ratownik, pośrednik pracowników, partner strategiczny (Popieluch, 2018, s. 15).

\section{Rysunek 1. Model funkcjonowania HR Biznes Partnera}

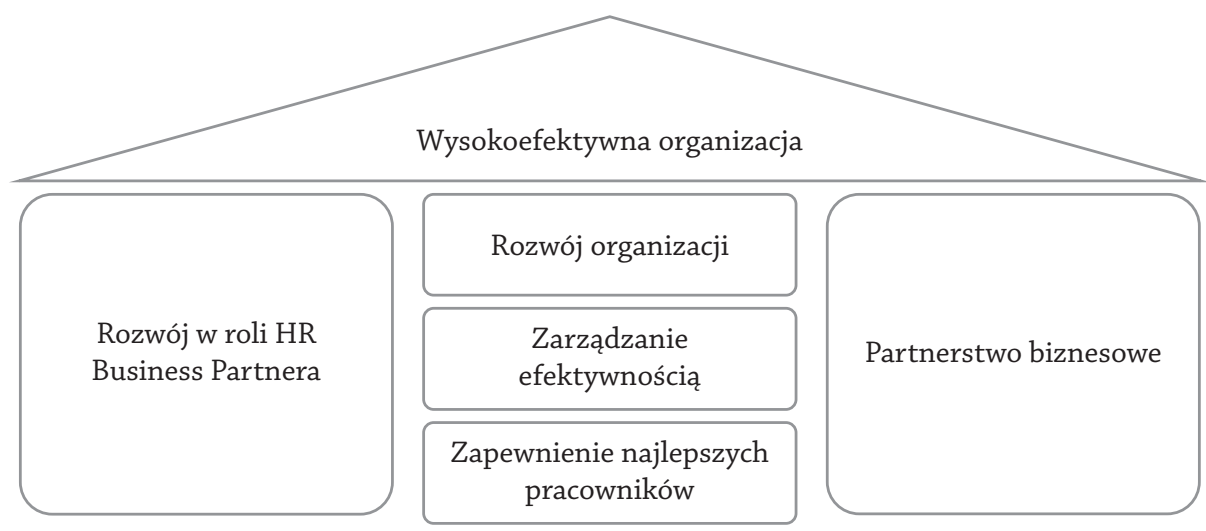

Źródło: Filipowicz (2016, s. 36). 
Filipowicz, przyjmując, że wszystkie działania tworzące podstawowe procesy biznesowe realizowane przez HR BP mają na celu służyć budowaniu wysokoefektywnych organizacji, skonstruował model funkcjonowania HR BP (rysunek 1).

\section{Tabela 1. Role HR BP i przypisane im zadania}

\begin{tabular}{|c|c|}
\hline Rola & Zadania \\
\hline $\begin{array}{l}\text { Menedżer } \\
\text { rozwoju } \\
\text { kapitału } \\
\text { ludzkiego }\end{array}$ & $\begin{array}{l}\text { - obsada stanowisk przez odpowiednie osoby } \\
\text { - czuwanie nad kompetencjami i predyspozycjami pracowników } \\
\text { - } \text { czuwanie nad zaangażowaniem i lojalnością pracowników } \\
\text { - } \text { gotowość do przyjmowania odpowiedzialności } \\
\text { - czuwanie nad stylem zarządzania i kulturą organizacyjną } \\
\text { - czuwanie nad komunikacją/przepływem informacji } \\
\text { - rozwój kapitału intelektualnego } \\
\text { - zarządzanie wiedzą }\end{array}$ \\
\hline Ekspert HR & $\begin{array}{l}\text { - } \text { rozwój organizacji } \\
\text { - zarządzanie efektywnością } \\
\text { - zapewnienie najlepszych pracowników } \\
\text { na odpewnienie obsługi administracyjno-prawnej w obszarze kadrowym } \\
\text { nam poziomie }\end{array}$ \\
\hline Agent zmian & $\begin{array}{l}\text { - działania na rzecz wdrażanych zmian - wbudowywanie postaw, wartości } \\
\text { i mechanizmów, które sprzyjać mogą zmianie kultury organizacyjnej } \\
\text { przedsiębiorstwa } \\
\text { odpowiedzialność za innowacje w organizacji, rozumiane jako „zdolność } \\
\text { wdrażania nowych i wartościowych dla organizacji rozwiązań” (Filipowicz, 2016, } \\
\text { 149-150) }\end{array}$ \\
\hline $\begin{array}{l}\text { Partner } \\
\text { strategiczny }\end{array}$ & $\begin{array}{l}\text { - wypełnianie części strategii firmy związanej z obszarem zarządzania kapitałem } \\
\text { ludzkim } \\
\text { - branie czynnego udziału w tworzeniu strategii przedsiębiorstwa }\end{array}$ \\
\hline $\begin{array}{l}\text { Rzecznik } \\
\text { pracowników }\end{array}$ & $\begin{array}{l}\text { - radzenie sobie z rywalizacją między pracownikami } \\
\text { - } \text { zarządzanie konfliktami między pracownikami } \\
\text { - } \text { zarządzanie konfliktami między menedżerami } \\
\text { rozstrzyca z partnerami społecznymi w realizacji planów biznesowych oraz } \\
\text { - reagowanie na zastrzeżenchia i uwagi pracowników } \\
\text { - odpowiadanie na bieżące pytania menedżerów liniowych i samych pracowników } \\
\text { - odpowiadanie na potrzeby zgłaszane przez pracowników } \\
\text { - odpowiadanie na potrzeby zgłaszane przez menedżerów } \\
\text { - reprezentowanie interesów pracowników na poziomie zarządczym } \\
\text { - wspieranie wszelkich procesów rozwoju zawodowego } \\
\text { - wspieranie pracowników i przełożonych w programach rozwojowych } \\
\text { - wynikających z systemu ocen } \\
\text { - pomagnie w ocenie potencjału zawodowego i budowaniu ścieżek kariery }\end{array}$ \\
\hline
\end{tabular}

Źródło: Filipowicz (2016). 
HR BP otrzymał w modelu dwa dodatkowe filary związane z własnym rozwojem w tej roli i bardziej biznesowym przygotowaniem do niej, a także partnerstwo biznesowe, w które powinien się angażować w organizacji. Na wszystkich pięciu polach działalności powinien oczywiście dążyć do zapewnienia efektywności organizacji jako całości, co jest nadrzędnym celem (Filipowicz, 2016, s. 35). Po ponad 20 latach doświadczeń od momentu stworzenia modelu przez Ulricha Filipowicz wskazał pięć podstawowych ról HR BP: menedżer rozwoju kapitału ludzkiego, ekspert HR, agent zmian, partner strategiczny oraz rzecznik pracowników (Filipowicz, 2016, s. 142). Do każdej z tych ról przypisane są określone zadania oraz wskaźniki efektywności (tabela 1 ).

Skok w 2009 r. opisał HR BP jako osobę dysponującą szeroką wiedzą, mającą kilkuletnie doświadczenie z obszaru „miękkiego” HR. Powinien on wspierać biznes w zakresie spraw personalnych. Skok zauważył, że stanowisko to występuje głównie w dużych, międzynarodowych firmach, w których duża liczba pracowników rozlokowanych w różnych działach wymaga wsparcia w obszarze HR (np. w firmie Antal). Analizując jego artykuł, Stosik, Głowicki i Zarecka (2011) wskazali na konieczność zwrócenia uwagi na orientację na klienta, efektywność kosztową, większą elastyczność w zakresie usług HR, innowacyjność w procesach i produktach oraz standaryzację procesów. Wśród obowiązków HR BP wymienili oni:

- prowadzenie rekrutacji wewnętrznych i zewnętrznych dla całej powierzonej grupy pracowniczej we współpracy z działami zgłaszającymi zapotrzebowanie,

- współpracę $z$ agencjami doradztwa personalnego,

- prowadzenie doradztwa w kwestii doboru personelu oraz procesu oceny kandydatów,

- dbałość o efektywność komunikacji pomiędzy działem HR a komórką odpowiedzialną za kwestie związane z płacami oraz administracją kadrowo-płacową,

- koordynację procesu oceny rocznej w przydzielonej grupie pracowników,

- koordynację działań rozwojowych w zakresie programów rozwojowych oraz programów naprawczych,

- archiwizację dokumentacji oraz systematyczne raportowanie w przyjętym systemie,

- aktywne uczestnictwo w procesie identyfikacji talentów wśród pracowników firmy, proponowanie rozwiązań mających na celu rozwój zawodowy pracowników,

- uczestnictwo w opracowywaniu planów szkoleniowych na bazie strategii szkoleń przyjętych w firmie, realizację szkoleń zgodnie z założeniami w konsultacji $z$ bezpośrednim przełożonym,

- uczestnictwo w tworzeniu systemów motywacyjnych oraz regulaminów dla przypisanej grupy pracowników,

- edukację i efektywną komunikację w zakresie istniejących regulaminów i polityki (Stosik, Głowicki, Zarecka, 2011). 
Zidentyfikowania rozbudowanej sieci relacji, która może opisać model skutecznego HR BP, podjął się Gołembski (2019). Sieć ta obejmuje współpracę i przepływ informacji pomiędzy HR Biznes Partnerami, zarządem organizacji, pracownikami i ich przełożonymi oraz specjalistami HR i zewnętrznymi dostawcami tych usług. Osoby na stanowisku HR BP stanowią istotną część biznesu, realnie wspierając członków organizacji w osiąganiu celów, włączając się w procesy biznesowe firmy, a także przynosząc wartość dodaną dla organizacji (Gołembski, 2019, s. 103).

\section{Wzorcowy zakres obowiązków HR Biznes Partnera - model własny}

Dogłębnie analizując opisaną powyżej literaturę w zakresie zarządzania zasobami ludzkimi, a bardziej szczegółowo w obszarze związanym z funkcją HR BP, stworzono wzorcowy zakres obowiązków dla tego stanowiska, włączając do niego te, które powtarzały się najczęściej w przytoczonych teoriach (tabela 2).

Tabela 2. Częstotliwość występowania obowiązków HR BP w literaturze

\begin{tabular}{|l|l|}
\hline \multicolumn{1}{|c|}{ Obowiązki HR BP } & Występowanie w literaturze \\
\hline $\begin{array}{l}\text { Udzielanie odpowiedzi na pytania menedżerów, wsparcie } \\
\text { w obszarze związanym z relacjami z pracownikami }\end{array}$ & $\begin{array}{l}\text { Ulrich, Storey, CLC, } \\
\text { Filipowicz }\end{array}$ \\
\hline $\begin{array}{l}\text { Udzielanie odpowiedzi na pytania pracowników, wsparcie } \\
\text { w obszarze personalnym }\end{array}$ & Ulrich, CLC, Filipowicz \\
\hline $\begin{array}{l}\text { Wdrażanie i realizacja strategii przedsiębiorstwa, w tym części } \\
\text { dotyczącej obszaru personalnego }\end{array}$ & $\begin{array}{l}\text { Armstrong, Ulrich, CLC, } \\
\text { Filipowicz }\end{array}$ \\
\hline $\begin{array}{l}\text { Wdrażanie zmian w przedsiębiorstwie dotyczących całej organizacji } \\
\text { bądź wybranych jej działów }\end{array}$ & Ulrich, CLC, Filipowicz \\
\hline $\begin{array}{l}\text { Identyfikowanie potrzeb rekrutacyjnych oraz prowadzenie } \\
\text { procesów rekrutacyjnych }\end{array}$ & $\begin{array}{l}\text { Ulrich, Stosik, Głowicki, } \\
\text { Zarecka, Filipowicz }\end{array}$ \\
\hline Przeprowadzanie procesu oceny pracowniczej & $\begin{array}{l}\text { Ulrich, CLC, Stosik, } \\
\text { Głowicki, Zarecka }\end{array}$ \\
\hline $\begin{array}{l}\text { Odpowiedzialność za określanie potrzeb szkoleniowych } \\
\text { pracowników oraz organizacja szkoleń }\end{array}$ & $\begin{array}{l}\text { Ulrich, Stosik, Głowicki, } \\
\text { Zarecka, Filipowicz }\end{array}$ \\
\hline $\begin{array}{l}\text { Tworzenie ścieżek kariery, programów rozwojowych, kierowanie } \\
\text { przepływem pracowników w firmie }\end{array}$ & $\begin{array}{l}\text { Ulrich, Stosik, Głowicki, } \\
\text { Zarecka, CLC, Filipowicz }\end{array}$ \\
\hline Identyfikacja i rozwój talentów w firmie & $\begin{array}{l}\text { CLC, Stosik, Głowicki, } \\
\text { Zarecka, Filipowicz }\end{array}$ \\
\hline Tworzenie oraz szerzenie kultury organizacyjnej firmy & Ulrich, CLC, Filipowicz \\
\hline $\begin{array}{l}\text { Rozwiązywanie sytuacji konfliktowych pomiędzy pracownikami } \\
\text { oraz na linii menedżer-pracownik, występowanie w roli mediatora }\end{array}$ & Ulrich, CLC, Filipowicz \\
\hline
\end{tabular}


cd. tabeli 2

\begin{tabular}{|l|l|}
\hline \multicolumn{1}{|c|}{ Obowiązki HR BP } & Występowanie w literaturze \\
\hline $\begin{array}{l}\text { Tworzenie, mierzenie, monitorowanie i komunikowanie polityki } \\
\text { i procedur HR }\end{array}$ & $\begin{array}{l}\text { Ulrich, Storey, CLC, } \\
\text { Stosik, Głowicki, Zarecka, } \\
\text { Filipowicz }\end{array}$ \\
\hline Budowanie partnerstwa biznesowego w firmie & $\begin{array}{l}\text { Ulrich, Gołembski, } \\
\text { Filipowicz }\end{array}$ \\
\hline Reprezentowanie interesów pracowników na poziomie zarządczym & Ulrich, Filipowicz \\
\hline Budowanie zaangażowania pracowników & Ulrich, Storey, Filipowicz \\
\hline Odpowiedzialność za komunikację i przepływ informacji w firmie & $\begin{array}{l}\text { Stosik, Głowicki, Zarecka, } \\
\text { Filipowicz }\end{array}$ \\
\hline $\begin{array}{l}\text { Opracowywanie strategii przedsiębiorstwa, w tym części dotyczącej } \\
\text { obszaru personalnego }\end{array}$ & $\begin{array}{l}\text { Armstrong, Ulrich, CLC, } \\
\text { Filipowicz }\end{array}$ \\
\hline Zapewnienie obsługi w zakresie administracji personalnej & Ulrich, Filipowicz \\
\hline
\end{tabular}

Źródło: opracowanie własne.

Na potrzeby dalszych badań przyjęto założenie, że aby osoba zajmująca stanowisko w Dziale HR mogła się tytułować HR Biznes Partnerem według tego wzorca, powinna ona w swoim zakresie obowiązków mieć minimum $70 \% \mathrm{z}$ wyżej wymienionych zakresów odpowiedzialności.

\section{Weryfikacja wzorcowego zakresu obowiązków HR Biznes Partnerów}

W badaniu własnym podjęto się weryfikacji wzorcowego zakresu obowiązków HR Biznes Partnerów poprzez porównanie z przykładami praktycznymi oraz badanie ankietowe przeprowadzone wśród pracowników działów HR. Poniżej opisano proces analizy dokumentacji wtórnej dwóch zakresów obowiązków HR Biznes Partnerów z różnych firm, które zostały zebrane w październiku 2018 r. Celem analizy było porównanie zakresów obowiązków dwóch stanowisk o jednakowej nazwie w różnych firmach, odnalezienie różnic i podobieństw między nimi, a także zestawienie ich ze wzorcowym zakresem obowiązków HR BP.

Pierwszy analizowany zakres obowiązków należał do HR BP pracującego w spółce notowanej na giełdzie, działającej na polskim rynku w obszarze telekomunikacji. Firma zatrudniała ok. 250 osób. Dział HR liczył pięć osób: HR Managera, dwóch Specjalistów ds. Kadr i Płac, HR Biznes Partnera oraz Specjalistę ds. BHP. W tym czasie firma prowadziła również rekrutację na stanowisko Młodszego Specjalisty ds. HR. Szczegółowy zakres obowiązków przypisany do stanowiska HR BP zawierał: 1) realizację procesów rekrutacyjnych, współpracę $z$ dostawcami usług rekrutacyjnych, 2) realizację procesu adaptacji, bieżące wsparcie dla nowych pracowników, 
3) realizację szkoleń i projektów rozwojowych,

4) realizację procesu oceny pracowniczej,

5) wsparcie w działaniach employer branding,

6) współpracę przy organizacji eventów firmowych,

7) kontrolę wybranych pozycji budżetowych HR w zakresie ustalonym z menedżerem HR,

8) tworzenie zestawień i raportów w zakresie obsługiwanych procesów HR,

9) tworzenie i wdrażanie procedur oraz narzędzi wspierających realizację procesów biznesowych w zakresie HR.

Odnosząc powyższy zakres obowiązków do opracowanego wzorca, można zauważyć, że realizacja procesu adaptacji, wsparcie w działaniach z zakresu employer branding, (wewnątrz i na zewnątrz organizacji, służących budowaniu reputacji pracodawcy wśród aktualnych i potencjalnych pracowników), współpraca przy organizacji imprez i wydarzeń firmowych nie występują we wzorcowym zakresie obowiązków. Poza tym kontrola wybranych pozycji budżetowych HR oraz tworzenie zestawień i raportów w zakresie obsługiwanych procesów HR nie są w nim wymienione bezpośrednio, lecz zaliczyć je można do tworzenia, mierzenia, monitorowania i komunikowania polityki i procedur HR. Niektóre z obowiązków wymienionych we wzorcu nie znalazły się w tym przykładzie z praktyki, tj.: udzielanie odpowiedzi na pytania menedżerów i pracowników (poza nowymi), opracowywanie, wdrażanie i realizacja strategii przedsiębiorstwa, wdrażanie zmian, identyfikacja i rozwój talentów, tworzenie i szerzenie kultury organizacyjnej, rozwiązywanie sytuacji konfliktowych, budowanie partnerstwa biznesowego w firmie, reprezentowanie interesów pracowników i budowanie ich zaangażowania, odpowiedzialność za komunikację i przepływ informacji, a także zapewnienie obsługi w obszarze administracji personalnej. Można więc wyliczyć, że procentowo zakres obowiązków z przykładu praktycznego wypełnia wzorzec w 27,8\% - 5 na 18 obowiązków.

Drugi przeanalizowany zakres obowiązków dotyczył roli HR BP w międzynarodowej firmie świadczącej usługi leasingowe, wchodzącej w skład większej, globalnej grupy kapitałowej banku. W firmie pracowało ok. 200 osób. Dział HR liczył pięć osób: Dyrektor HR, Ekspert ds. Kadr i Płac, HR Biznes Partner, Specjalista ds. Zarządzania Zasobami Ludzkimi oraz Asystent HR. Zakres obowiązków na stanowisku HR BP obejmował:

1) realizowanie zadań związanych z polityką personalną firmy,

2) realizowanie rekrutacji oraz wdrożenia pracowników,

3) koordynowanie procesu zarządzania wynikami pracy - tj. oceny roczne, wyznaczanie celów, regularna informacja zwrotna,

4) realizowanie działań związanych z programami rozwojowymi i szkoleniami,

5) koordynowanie procesu badania zaangażowania pracowników,

6) realizowanie działań związanych z karierą, sukcesją i talentami, 
7) komunikacja wewnętrzna i budowanie wizerunku pracodawcy na rynku,

8) przygotowywanie analiz, raportowanie, monitorowanie w zakresie wyżej wymienionych procesów,

9) wsparcie w zakresie administracji personalnej i płac,

10) wsparcie w zakresie polityki wynagrodzeń i benefitów oraz ZFŚS (Zakładowego Funduszu Świadczeń Socjalnych),

11) współudział w tworzeniu procedur/instrukcji dotyczących funkcjonowania działu personalnego,

12) wykonywanie innych czynności administracyjnych zleconych przez przełożonego, związanych z zapewnieniem prawidłowego i efektywnego funkcjonowania działu personalnego.

Z wymienionych zadań we wzorcowym zakresie obowiązków nie odnajdujemy wdrażania pracowników oraz budowania wizerunku pracodawcy na rynku. Natomiast przygotowywanie analiz, raportowanie, monitorowanie w zakresie procesów HR czy wsparcie w zakresie polityki wynagrodzeń i benefitów oraz ZFŚS możemy niebezpośrednio połączyć z tworzeniem, mierzeniem, monitorowaniem i komunikowaniem polityki i procedur HR. Obowiązki z opracowanego wzorca, które nie znalazły się w tym przykładzie z praktyki, to: udzielanie odpowiedzi na pytania menedżerów i pracowników, opracowywanie, wdrażanie i realizacja strategii przedsiębiorstwa, wdrażanie zmian, tworzenie i szerzenie kultury organizacyjnej, rozwiązywanie sytuacji konfliktowych, budowanie partnerstwa biznesowego w firmie oraz reprezentowanie interesów pracowników. Procentowo zakres obowiązków z tego przykładu praktycznego wypełnia wzorzec w 50\% - 9 na 18 obowiązków.

\section{Tabela 3. Różnice w zakresach obowiązków HR Biznes Partnerów w badanych} przedsiębiorstwach

\begin{tabular}{|l|l|}
\hline \multicolumn{1}{|c|}{ HR BP - firma telekomunikacyjna } & \multicolumn{1}{|c|}{ HR BP - firma leasingowa } \\
\hline Współpraca przy organizacji & Realizowanie polityki personalnej, a także polityki \\
wydarzeń skierowanych do & wynagrodzeń i Zakładowego Funduszu Świadczeń \\
pracowników firmy & Socjalnych, dodatkowo obowiązki, jakie znajdują się tylko \\
Odpowiedzialność za część budżetu & w tym zakresie oraz we wzorcowym zakresie obowiązków, \\
Działu HR & to odpowiedzialność za badanie zaangażowania \\
& pracowników, realizowanie działań związanych z karierą, \\
& sukcesją i talentami, odpowiedzialność za komunikację \\
& wewnętrzną w firmie oraz obowiązki wspierające \\
& w obszarze administracji personalnej i płac \\
\hline
\end{tabular}

Źródło: opracowanie własne.

Obydwa zakresy obowiązków zawierają procesy związane z:

- rekrutacją pracowników,

- wdrożeniem nowych pracowników, 
- zarządzaniem szkoleniami i projektami rozwojowymi,

- realizacją procesu oceny pracowniczej,

- budowaniem wizerunku pracodawcy na zewnątrz organizacji,

- przygotowywaniem analiz, zestawień i raportów dotyczących HR.

Obszar, który występuje w obydwu zakresach obowiązków, dotyczy tworzenia i wdrażania procedur wspierających funkcjonowanie działu HR oraz realizację jego procesów - jednak w pierwszym przypadku jest to pełna odpowiedzialność, natomiast w firmie z sektora finansowego jedynie współudział. Różnice występujące pomiędzy przytoczonymi zakresami obowiązków opisano w tabeli 3.

\section{Analiza badania przeprowadzonego wśród pracowników działów HR}

W celu zbadania funkcji HR Biznes Partnerów, zakresu ich obowiązków oraz uprawnień we współczesnych organizacjach i zgodności z opracowanym wzorcowym zakresem obowiązków - przygotowano badanie w formie wystandaryzowanego scenariusza. Respondentami kwestionariusza ankiety było 68 pracowników zajmujących stanowiska w działach HR. Badanie wykonano na przełomie czerwca i lipca 2019 r., kierując kwestionariusz bezpośrednio do pracowników działów HR. Kwestionariusz ankiety zawierał opracowany i przedstawiony powyżej wzorcowy zakres obowiązków HR BP, w rozbudowanej formie do 24 funkcji, w celu większego uszczegółowienia badań. Jedno z pytań dotyczyło również wielkości organizacji, w której pracuje respondent: mikroprzedsiębiorstwo zatrudniające mniej niż 10 osób, małe przedsiębiorstwo zatrudniające mniej niż 50 osób, średnie przedsiębiorstwo zatrudniające mniej niż 250 osób, duże przedsiębiorstwo zatrudniające 250 osób lub więcej. Na ankietę odpowiedziało 12 osób zajmujących stanowiska HR Biznes Partnerów, a także po jednej osobie zajmującej stanowiska Human Resource Business Support oraz People \& Culture Business Partner, które uznano za pochodną od nazwy HR BP, łącznie 14 respondentów. Uzyskano następujące informacje na temat działań respondentów:

- $100 \%$ jest odpowiedzialnych za budowanie zaangażowania, odpowiadanie na pytania pracowników i menedżerów,

- $93 \%$ rozwiązuje sytuacje konfliktowe i występuje w roli mediatora, a także tworzy i szerzy kulturę organizacyjną przedsiębiorstwa,

- $85 \%$ identyfikuje i rozwija talenty w firmie, prowadzi procesy oceny pracowniczej, a także jest odpowiedzialne za wdrażanie zmian w przedsiębiorstwie,

- 78\% respondentów posiada w swoim zakresie obowiązków budowanie partnerstwa biznesowego w firmie oraz tworzenie programów rozwojowych, 
- $71 \%$ identyfikuje potrzeby rekrutacyjne, prowadzi procesy rekrutacyjne oraz tworzy ścieżki kariery,

- $64 \%$ jest odpowiedzialne za komunikację i przepływ informacji w firmie oraz kierowanie przepływem pracowników,

- $57 \%$ reprezentuje interesy pracowników na poziomie zarządczym,

- $78 \%$ tworzy polityki i procedury, $85 \%$ odpowiada za ich monitorowanie i mierzenie, a $78 \%$ je komunikuje,

- $78 \%$ odpowiada za określanie potrzeb szkoleniowych pracowników, a 36\% organizuje szkolenia,

- 57\% opracowuje i wdraża strategię przedsiębiorstwa, w tym część dotyczącą obszaru personalnego, natomiast realizację strategii zadeklarowało $78 \%$ respondentów,

- najniższy odsetek na poziomie $43 \%$ uzyskała odpowiedź dotycząca zapewnienia obsługi w zakresie administracji personalnej.

Respondenci obejmujący stanowisko HR BP wypełniają wzorcowy zakres obowiązków na poziomie:

- $100 \%$ - tylko jedna z osób ankietowanych pracująca w małym przedsiębiorstwie,

- $92 \%$ - jedna $\mathrm{z}$ ankietowanych osób pracująca w dużym przedsiębiorstwie,

- 83\% - trzy osoby pracujące w dużych przedsiębiorstwach,

- $79 \%$ - dwie osoby pracujące w dużych przedsiębiorstwach, w tym osoba na stanowisku People \& Culture Business Partner,

- $71 \%$ - trzy osoby, dwie pracujące w dużych przedsiębiorstwach, zaś jedna w małym przedsiębiorstwie,

- $67 \%$ - trzy osoby, dwie pracujące w dużych przedsiębiorstwach i jedna pracująca w mikro przedsiębiorstwie,

- $50 \%$ - jedna osoba pracująca w średnim przedsiębiorstwie na stanowisku HR Business Support.

Wzorcowy zakres obowiązków uznaje się za spełniony w przedsiębiorstwie, kiedy HR BP wypełnia go w minimum 70\%, tj. wykonuje przynajmniej 17 z 24 wymienionych obowiązków. Przy takim założeniu można uznać, że 10 z 14 ankietowanych HR Biznes Partnerów wypełnia opracowany wzorcowy zakres obowiązków na poziomie minimum $70 \%$ i więcej, a co za tym idzie zadania HR Biznes Partnerów są realizowane $\mathrm{w}$ przedsiębiorstwie zgodnie $\mathrm{z}$ teorią.

Praca badanych HR Biznes Partnerów częściowo różni się wykonywanymi zadaniami. Może to wynikać z różnej budowy działów HR oraz innych stanowisk w nich występujących. W podanej grupie badanych nie ma to jednak bezpośredniego związku z wielkością przedsiębiorstwa, gdyż nie da się zauważyć jakiegokolwiek powiązania.

Wśród respondentów niezajmujących stanowisk HR Biznes Partnerów aż 24 z 54 osób spełniły warunek pełnienia funkcji HR Biznes Partnera, wypełniając wzorcowy 
zakres obowiązków w ponad 70\%. Stopień zgodności ze wzorcem wśród osób spełniających warunek minimum wynosił:

- $100 \%$ - dwie osoby zajmujące stanowiska w średnich przedsiębiorstwach: Specjalista ds. Rekrutacji oraz Kierownik Działu Personalnego,

- $96 \%$ - dwie osoby zajmujące stanowiska Head of HR oraz HR Managera w średnich przedsiębiorstwach,

- $92 \%$ - cztery osoby zajmujące stanowiska Corporate HR Managera (duże przedsiębiorstwo), Specjalisty ds. Rekrutacji i Projektów HR (średnie przedsiębiorstwo) oraz dwóch HR Managerów (małe i średnie przedsiębiorstwo),

- $88 \%$ - jedna osoba zajmująca stanowisko Starszego Specjalisty ds. HR w dużym przedsiębiorstwie,

- 83\% - sześć osób zajmujących stanowiska HR and Payroll Specialist (mikroprzedsiębiorstwo), Head of HR and Administration i HR Manager (małe przedsiębiorstwo), HR Specialist i Młodszy Specjalista ds. Personalnych (średnie przedsiębiorstwo), Specjalista ds. Personalnych (duże przedsiębiorstwo),

- 79\% - pięć osób zajmujących stanowiska Doradca SHRM, Specjalista ds. HR oraz Kierownik Wydziału Rozwoju i Employer Brandingu w dużych przedsiębiorstwach, a także Head of HR i HR Manager w średnich przedsiębiorstwach,

- $75 \%$ - jedna osoba zajmująca stanowisko Młodszego Specjalisty ds. HR w średnim przedsiębiorstwie,

- $71 \%$ - trzy osoby zajmujące stanowiska Kierownika Zespołu Rekrutacji oraz HR Generalist w dużych przedsiębiorstwach, a także HR Executive w średnim przedsiębiorstwie.

Analiza wyników kwestionariusza ankiety pozwala zauważyć, jak różne obowiązki wypełniają osoby zajmujące te same stanowiska. W analizowanej grupie respondentów brak jest spójności w nazwach stanowisk i w realizowanych na nich zadaniach. Tę grupę badanych można odnieść do rynku pracy HR, na którym często dopiero określenie zadań daje jasny obraz, czym dana osoba się zajmuje, a sama nazwa stanowiska niewiele mówi o zakresie odpowiedzialności.

\section{Podsumowanie}

Koncepcja HR Biznes Partnera stworzona przez Dave’a Ulricha była wielokrotnie rozważana przez innych badaczy zarządzania zasobami ludzkimi, jak również przekształcana przez samego autora. W artykule przywołano koncepcje, których analiza pozwoliła stworzyć wzorcowy zakres obowiązków HR BP. W jego treści znalazły się najczęściej powtarzające się w opracowaniach różnych autorów zadania przypisywane HR Biznes Partnerom. Dzięki porównaniu wzorcowego zakresu obowiązków 
z przykładami praktycznymi oraz wynikami badania ankietowego przeprowadzonego wśród pracowników HR stwierdzono, że nazwa stanowiska HR BP nie zawsze odnosi się do tych samych zadań przypisanych tej roli. Obowiązki oraz zakres odpowiedzialności HR Biznes Partnerów w poszczególnych organizacjach różnią się od siebie. Zauważono również przypadki, kiedy osoby nieobejmujące stanowiska HR BP w rzeczywistości spełniają taką funkcję we współczesnych firmach, wypełniając na określonym, minimalnym poziomie wzorcowy zakres obowiązków. Fakty, które wynikają z przeprowadzonej analizy i badań, świadczą o stosowaniu w praktyce funkcji HR BP niezgodnie z dostępną teorią na ten temat. Organizacje nie zawsze nadają odpowiednie nazwy stanowisk osobom wykonującym wzorcowy zakres obowiązków HR BP. Zjawisko to funkcjonuje w dwie strony. Występują zarówno pracownicy piastujący to stanowisko, jednak niespełniający tej funkcji, jak również ci, którzy funkcję tę spełniają, jednak nazwa ich stanowiska jest zgoła inna. Przy tworzeniu nazw stanowisk oraz odpowiadających im zakresów obowiązków właściwe osoby powinny się zapoznać z teorią dotyczącą tej dziedziny. Niniejszy artykuł może stanowić punkt wyjścia do dalszych badań teoretycznych, a także być pomocny w tworzeniu stanowisk HR Biznes Partnerów w Działach HR oraz w wyłanianiu osób sprawujących tę funkcję spośród obecnych pracowników.

\section{Bibliografia}

Armstrong, M. (2016). Zarzq̨dzanie zasobami ludzkimi. Warszawa: Wolters Kluwer.

Bogdanowicz, M. (2016). Zarzadzanie zasobami ludzkimi - Refleksje teoretyczne, kwestie praktyczne. Warszawa: WSFiZ.

Filipowicz, G. (2017). HR Business Partner - praktyczne rozwiqzania wysokoefektywnych organizacji. Warszawa: Infor.

Filipowicz, G. (2016). HR Business Partner - koncepcja i praktyka. Warszawa: Wolters Kluwer.

Głowicki, P., Stosik, A., Zarecka, E. (2011). HR business partner - nowa rola w zarządzaniu zasobami ludzkimi. W: J. Skalik, G. Bełz (red.), Strategiczne i operacyjne problemy rozwoju i wzrostu przedsiębiorstwa, Wrocław: Wydawnictwo Uniwersytetu Ekonomicznego we Wrocławiu, nr 218, 242-248.

Gołembski, M. (2019). Funkcja personalna w przedsiębiorstwie - aktualne trendy i perspektywy rozwoju. Warszawa: $\mathrm{CeDeWu}$.

Juchnowicz, M. (2014). Zarządzanie zasobami ludzkimi. Warszawa: PWE.

Pocztowski, A. (2018). Zarzqqdzanie zasobami ludzkimi. Warszawa: PWE.

Popieluch, K. (2018). HR Business Partner - rola, filary, perspektywy. Warszawa: WN PWN. Skok, R. (2009). HR Business Partner - potrzeba dzisiejszych czasów?. https://antal.pl/ wiedza/artykul/hr-business-partner-potrzeba-dzisiejszych-czasow, 12.03.2019. 
Ulrich, D. (2001). Liderzy zarządzania zasobami ludzkimi. Warszawa: Oficyna Ekonomiczna. Zakres obowiązków HR Biznes Partnera firmy telekomunikacyjnej.

Zakres obowiązków HR Biznes Partnera firmy leasingowej.

\title{
Abstract \\ HR Business Partner - Genesis and Functions in Modern Organizations
}

\begin{abstract}
The article describes one of trends appearing in human resources management, which is HR Business Partner concept. The theory connected with general area of human resources management and with mentioned conception was analysed and described by the author. As a result a model job description of HR Business Partner role was created. Than formed job description was compared with practical examples in analysis of internal documents from two companies and questionnaire survey conducted among HR Department employees from different companies. Results of those studies show that the job title - HR Business Partner, not always refers to the tasks assigned by the author to this role. And vice versa - fulfilment of model job description at minimum level by HR Department employees not always brings with it an HR Business Partner job title.
\end{abstract}

Keywords: human resources management, HR, HR Business Partner, job description, job title

\section{Mgr Milena Rogala}

\begin{abstract}
Absolwentka studiów licencjackich Wydziału Zarządzania Uniwersytetu Warszawskiego na kierunku Finanse, rachunkowość i ubezpieczenia, w trakcie których przez semestr studiowała Ekonomię na Uniwersytecie w Weronie w ramach wymiany międzynarodowej Erasmus+. Absolwentka studiów magisterskich Szkoły Głównej Handlowej na kierunku Zarządzanie, ze specjalizacjami Zarządzanie zasobami ludzkimi oraz Zarządzanie projektami. Ma ponad pięcioletnie doświadczenie w pracy w Dziale HR w różnych organizacjach. Obecnie zajmuje stanowisko Koordynatora - Regionalnego Junior HR Biznes Partnera w firmie PZU. Zainteresowania: zarządzanie zasobami ludzkimi, ze szczególnym uwzględnieniem funkcji HR Biznes Partnera, oraz zarządzanie projektami i zmianami w organizacjach.

e-mail: milenaarogala@gmail.com

ORCID: 0000-0002-8706-8790
\end{abstract}

